\title{
Geomorphometric Characterization of Upper South Koel Basin, Jharkhand: A Remote Sensing \& GIS Approach
}

\author{
Reshma Parveen $^{1 *}$, Uday Kumar ${ }^{1}$, Vivek Kumar Singh ${ }^{2}$ \\ ${ }^{1}$ Department of Geology, Ranchi University, Ranchi, India \\ ${ }^{2}$ Department of Geology \& Mining, CIAL, Abhijeet Group, Nagpur, India \\ Email: res1077@gmail.com, kumaruday10@gmail.com, vivekearth@gmail.com
}

Received September 28, 2012; revised November 1, 2012; accepted November 10, 2012

\begin{abstract}
The quantitative analysis of drainage system is an important aspect of characterization of watersheds. Morphometry is measurement and mathematical analysis of landforms. The present study is an attempt to evaluate the drainage morphometrics of Upper South Koel Basin using Remote Sensing and GIS approach. A morphometric analysis was carried out to describe the topography and drainage characteristics of Upper South Koel watershed. The stream numbers, orders, lengths and other morphometric parameters like bifurcation ratio, drainage density, stream frequency, shape parameters etc. were measured. The drainage area of Upper South Koel watershed is $942.4 \mathrm{sq} \mathrm{km}$ and the drainage pattern is dentritic. The watershed was classified as $6^{\text {th }}$ order drainage basin. The low values of bifurcation ratio and drainage density suggest that the area has not been much affected by structural disturbances. The study reveals that the different geomorphic units in the study area i.e. Structural hills, Pediments, Valley fills, Pediplains formed under the influence of permeable geology, are moderate to nearly level plains, with medium to low drainage density $(<2.0)$ \& low cumulative length of higher order streams. Such studies can be of immense help in planning and management of river basins.
\end{abstract}

Keywords: Morphometry; Watershed; Remote Sensing; GIS

\section{Introduction}

River basins comprise a distinct morphologic region and have special relevance to drainage pattern and geomorphology $[1,2]$. The total development of a region is a sum total development of sub basins of which it is composed. So by analyzing the development of each of the sub basins one can have a better understanding of the landscape of the terrain. This is possible only when relationship among the forms of individual drainage basins and process at work within them that led to development of a ba$\sin$ as a whole is established.

Prior to 1945 such studies were concentrated on quailtative and deductive aspects. A new era of quantitative analysis was initiated by Horton in 1945 who first applied the technique of quantitative analysis of drainage basins. Morphometric analysis involves evaluation of streams through the measurement of various stream properties, analysis of various drainage parameters namely ordering of the various streams and measurement of area of basin, perimeter of basin, length of drainage channels, drainage density $\left(D_{d}\right)$, drainage frequency, bifurcation ratio $\left(R_{b}\right)$, texture ratio $(T)$, circulatory ratio $\left(R_{c}\right)$, basin relief $\left(\mathrm{B}_{\mathrm{h}}\right)$ and length of overland flow $\left(\mathrm{L}_{\mathrm{g}}\right)$ to predict the

"Corresponding author. approximate behavior of the watersheds during periods of heavy rainfall $[3,4]$. Surface drainage characteristics of many river basins and sub basins in different parts of the globe have been studied using conventional methods [5-10]. The present study describes the capabilities of Remote Sensing and GIS to study the drainage characteristics of Upper South Koel river basin in order to understand their hydrological behavior.

\section{Study Area}

The watershed is a part of South Koel basin with an area of $942.4 \mathrm{sq} \mathrm{km}$ bounded by latitude $23^{\circ} 17^{\prime} 16^{\prime \prime} \mathrm{N}$ \& $23^{\circ} 32^{\prime} 16^{\prime \prime} \mathrm{N}$ and longitude $84^{\circ} 14^{\prime} 15^{\prime \prime} \mathrm{E} \& 8^{\circ} 46^{\prime} 51^{\prime \prime} \mathrm{E}$ (Figure 1). It lies in SOI topo sheet no $73 \mathrm{~A} / 14,73 \mathrm{~A} / 15$, $73 \mathrm{E} / 2,73 \mathrm{E} / 3$ covering Lohardaga and Ranchi districts of Jharkhand. South Koel is the main river in the study area with Kandani and Saphi River as its major tributaryies. The drainage pattern is mainly dendritic. The climate of the area is subtropical. The annual rainfall in the region is $1400 \mathrm{~mm}$, on an average of which $82.1 \%$ is received during the periods June to September and the rest $17.9 \%$ in remaining months. Temperature is lowest during December and January with mean minimum of $9^{\circ} \mathrm{C}$ and highest during April and May with mean maximum of $37.2^{\circ} \mathrm{C}$. 


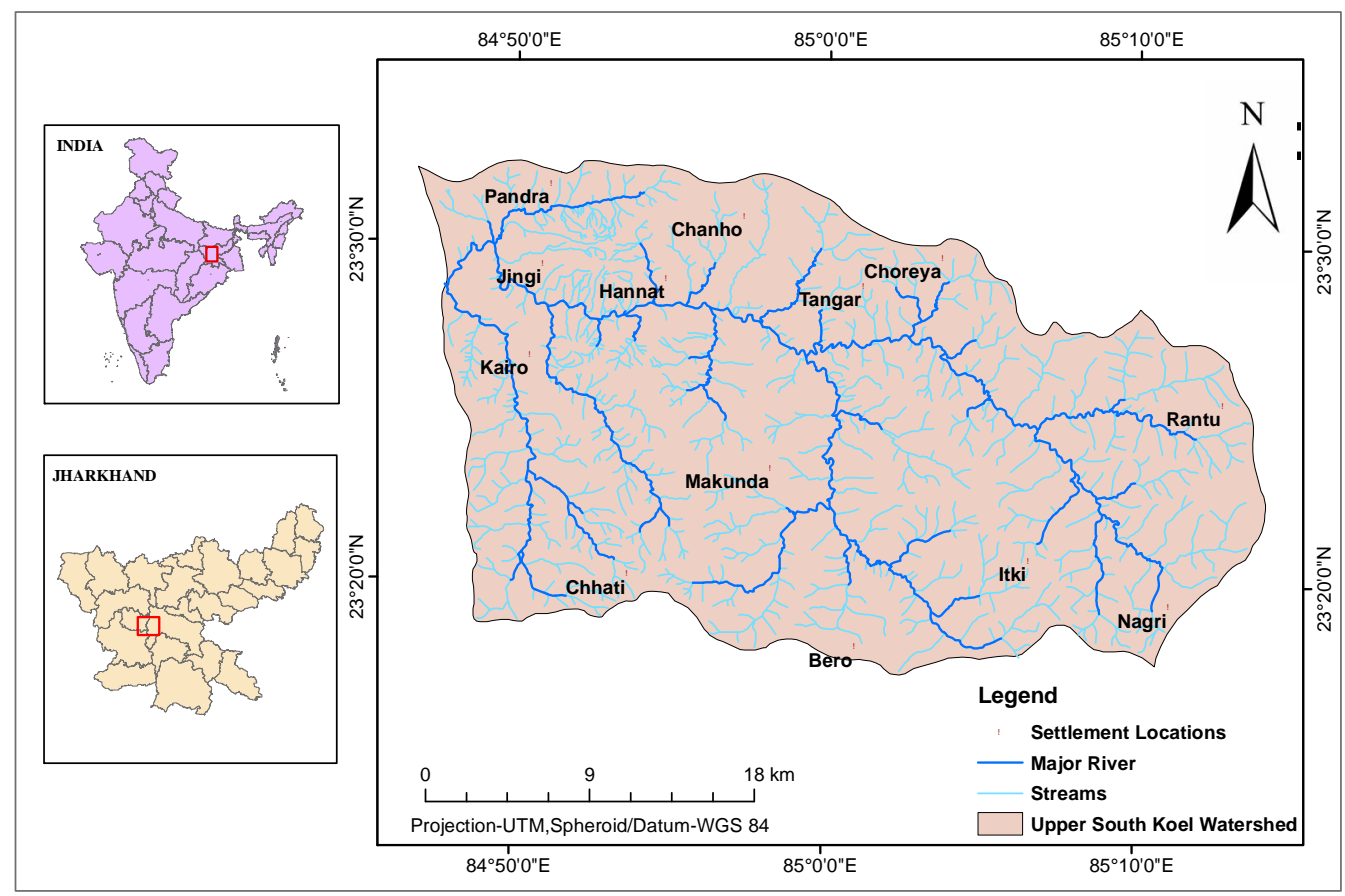

Figure 1. Location map of study area.

\section{Lithology \& Structure}

Stream processes in any terrain are not only controlled by climatic conditions, but also the lithology and geologic structure have great control as they influence the nature of flow, erosion and sediment transportation. Geologically the oldest rocks encountered in the area are unclassified metamorphic represented by Mica Schist, Hornblende schist and amphibolites which form the basement rocks in the study area. The overlying Chotanagpur Gneissic complex comprising Granite Gneiss forms the most widespread outcrop in the study area. Laterite, Metabasic dykes and recent alluvial deposits are other rock types encountered in the area.

Structures are linear geomorphic features that are the surface expression of zones of weakness or structural displacement in the crust of the earth and have an important role to play in development of drainage network of the region. The area has experienced structural disturbances leading to development of well marked set of joints and fractures. The main fractures/joints are along NE-SW, N-S, E-W, NW-SE direction. A fault trending $\mathrm{N} 70^{\circ} \mathrm{W}-\mathrm{S} 70^{\circ} \mathrm{E}$ has also been traced in the area. Figure 2 shows the geological map of the study area.

\section{Hydrogeology}

The study area is having varied hydro-geological characteristics due to which ground water potential differs from one region to another. Two types of aquifers are found. Weathered aquifer and fractured aquifers. In weathered aquifer ground water occurs in unconfined condition while in fractured aquifer ground water occurs in semi confined to confined condition. Thickness of weathered aquifers varies from $10-25 \mathrm{~m}$ in granite terrain and 30 $60 \mathrm{~m}$ in lateritic terrain. In fractured aquifers, first fracture occurs between $50-70 \mathrm{~m}$, second fracture occurs between $100-120 \mathrm{~m}$ and third set of fracture can be found between $150-200 \mathrm{~m} \mathrm{bgl} \mathrm{depth}$.

\section{Methodology}

Drainage networks and other baseline information of the watershed were prepared from the Survey of India toposheets on 1:50,000 scale and were further updated using satellite data. IRS - P6 LISS IV data of study area co-registered to Survey of India toposheet was used for the updation. ASTER $30 \mathrm{~m}$ DEM was also used for the study. Using the DEM slope map of the watershed was prepared.

In GIS the channel segments were ordered numerically as order number 1 from a stream's headwaters to a point downstream. The stream segment that results from the joining of two first order streams was assigned order 2 and so on. Watershed parameters, such as: Basin area (A), Basin perimeter $(\mathrm{P})$, Basin length $\left(\mathrm{L}_{\mathrm{b}}\right)$, Stream length $(\mathrm{L})$, and Stream order $(\mathrm{N})$ were calculated. These parameters were used to determine other influencing factors, such as Bifurcation ratio, Stream frequency, Drainage density, Texture ratio, Basin relief, elongation ratio, circulatory ratio, form factor and Length of Overland flow. Table 1 


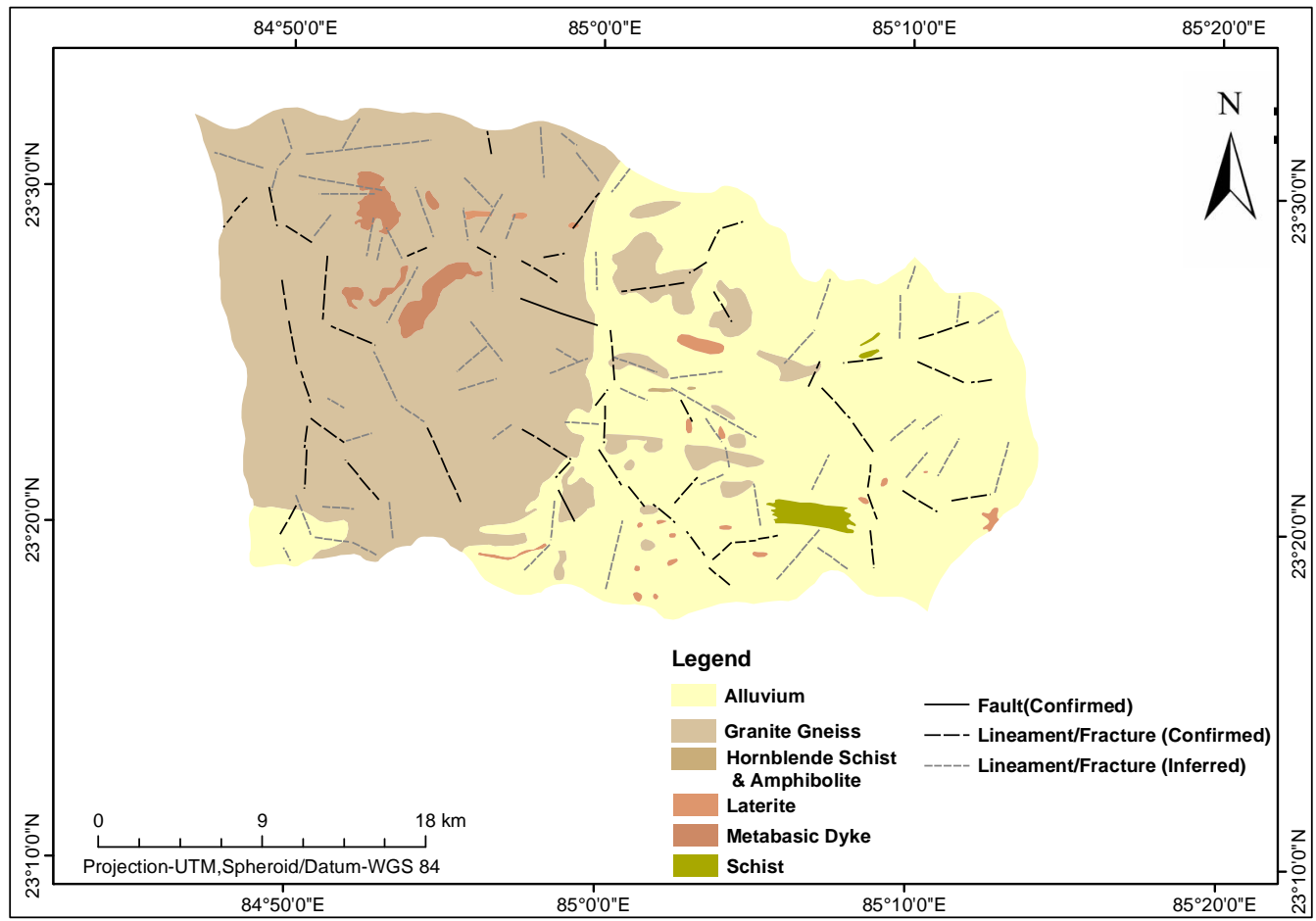

Figure 2. Geological map of study area.

Table 1. Morphometric parameters and their mathematical expressions.

\begin{tabular}{|c|c|c|c|c|}
\hline Sl. No. & Parameters & Formulae & Reference & Description \\
\hline 1 & Stream Order (U) & Hierarchical Rank & Strahler (1964) & \\
\hline 2 & $\begin{array}{l}\text { Cumulative Length of } \\
\text { Streams (L) }\end{array}$ & $\mathrm{L}=\Sigma \mathrm{Nu}$ & Horton (1945) & $\begin{array}{l}\mathrm{L} \text { was calculated as the number of streams in each } \\
\text { order and total length of each order was computed at } \\
\text { sub basin level. }\end{array}$ \\
\hline 3 & Bifurcation Ratio $\left(\mathrm{R}_{\mathrm{b}}\right)$ & $\mathrm{R}_{\mathrm{b}}=\mathrm{Nu} /(\mathrm{Nu}+1)$ & Schumm (1956) & $\begin{array}{c}\mathrm{R}_{\mathrm{b}} \text { was computed as the ratio between the number of } \\
\text { streams of any given order to the number of streams } \\
\text { in the next higher order. }\end{array}$ \\
\hline 4 & Basin Relief $\left(B_{h}\right)$ & $\mathrm{B}_{\mathrm{h}}=\mathrm{h}_{\max }-\mathrm{h}_{\min }$ & $\begin{array}{l}\text { Hadley and Schumm } \\
\text { (1961) }\end{array}$ & $\begin{array}{c}\mathrm{B}_{\mathrm{h}} \text { was defined as the maximum vertical distance } \\
\text { between the lowest and the highest points } \\
\text { of a sub basin. }\end{array}$ \\
\hline 5 & Drainage Density $\left(D_{d}\right)$ & $\mathrm{D}_{\mathrm{d}}=\mathrm{L} / \mathrm{A}$ & Horton (1945) & $\begin{array}{c}\mathrm{D}_{\mathrm{d}} \text { was measured as the length of stream channel per } \\
\text { unit area of drainage basin. }\end{array}$ \\
\hline 7 & Texture Ratio (T) & $\mathrm{T}=\mathrm{D}_{\mathrm{d}} \times \mathrm{F}_{\mathrm{u}}$ & Smith (1950) & $\begin{array}{l}\mathrm{T} \text { was estimated as the product of drainage density } \\
\text { and stream frequency. }\end{array}$ \\
\hline 8 & Form Factor $\left(\mathrm{R}_{\mathrm{f}}\right)$ & $\mathrm{R}_{\mathrm{f}}=\mathrm{A} /\left(\mathrm{L}_{\mathrm{b}}\right)^{2}$ & Horton (1945) & $\begin{array}{l}\mathrm{R}_{\mathrm{f}} \text { was computed as the ratio between the basin area } \\
\text { and square of the basin length. }\end{array}$ \\
\hline 9 & Elongation Ratio $\left(\mathrm{R}_{\mathrm{e}}\right)$ & $\mathrm{Re}=2 / \mathrm{L}_{\mathrm{b}} \times \sqrt{\mathrm{A} / \pi}$ & Miller (1953) & $\begin{array}{c}\mathrm{R}_{\mathrm{e}} \text { was computed as the ratio between the diameter of } \\
\text { the circle having the same area as that of basin } \\
\text { to the basin length. }\end{array}$ \\
\hline 10 & Circulatory Ratio $\left(\mathrm{R}_{\mathrm{c}}\right)$ & $\mathrm{R}_{\mathrm{c}}=4 \pi \mathrm{A} / \mathrm{P}^{2}$ & Strahler (1964) & $\begin{array}{l}\mathrm{R}_{\mathrm{c}} \text { is defined as the area of the basin to the area of a } \\
\text { circle having the same circumference as the perimeter } \\
\text { of the basin. }\end{array}$ \\
\hline 11 & $\begin{array}{l}\text { Length of Overland Flow } \\
\qquad\left(\mathrm{L}_{\mathrm{o}}\right)\end{array}$ & $\mathrm{C}=1 / 2 \times 1 / \mathrm{D}_{\mathrm{d}}$ & Horton (1945) & $\begin{array}{c}\mathrm{L}_{\mathrm{o}} \text { is expressed as half of reciprocal of } \\
\text { drainage density. }\end{array}$ \\
\hline
\end{tabular}


provides a list of the main parameters with their description and the formulae used to calculate them.

\section{Result and Discussion}

The total drainage area of Upper South Koel watershed is $942.40 \mathrm{sq} \mathrm{km}$ and has been divided into four sub basins based on water divide concept for morphometric analysis (Figure 3). The development of drainage network in a region is dependent on the lithology, structure, topography, rainfall apart from endogenetic and exogenic influences. The drainage is mainly dentritic. Based on drainage order, the watershed has been classified as sixth order basin.

Morphometric analysis of drainage network developed in the study area can help a lot in understanding the geomorphic processes and hydrological characteristic of the watersheds under study. The linear, relief and areal aspects of the watershed and sub-basins have been analyzed to understand the morphometrics of the basin.

\subsection{Linear Aspects}

Computation of the linear aspects such as stream order, stream number for various orders, bifurcation ratio, stream lengths for various stream orders and length ratio are described below. The linear aspect computations of the basin and the sub-basins are presented in Tables 2(a) and (b).

\subsubsection{Stream Number $\left(\mathbf{N}_{\mathrm{u}}\right)$}

It is obvious that the total number of streams gradually decreases as the stream order increases. With the application of GIS, the number of streams of each order and the total number of streams was computed.

\subsubsection{Stream Order (U)}

Stream ordering was done based on the method proposed by Strahler [7].The streams with no tributaries are designated as order 1 . These channels normally flow only during wet conditions. The second order streams are those having first order streams as its tributaries. When two second order streams join they give rise to third or- der streams and so on. When streams of different orders join, they give rise to a stream having higher value among the two.

Application of this ordering procedure through GIS shows that the drainage network of the study area is of sixth order. Among the sub-basins, sub-basin I is of sixth order whereas sub-basin II, sub-basin III and sub-basin IV are of fifth order.

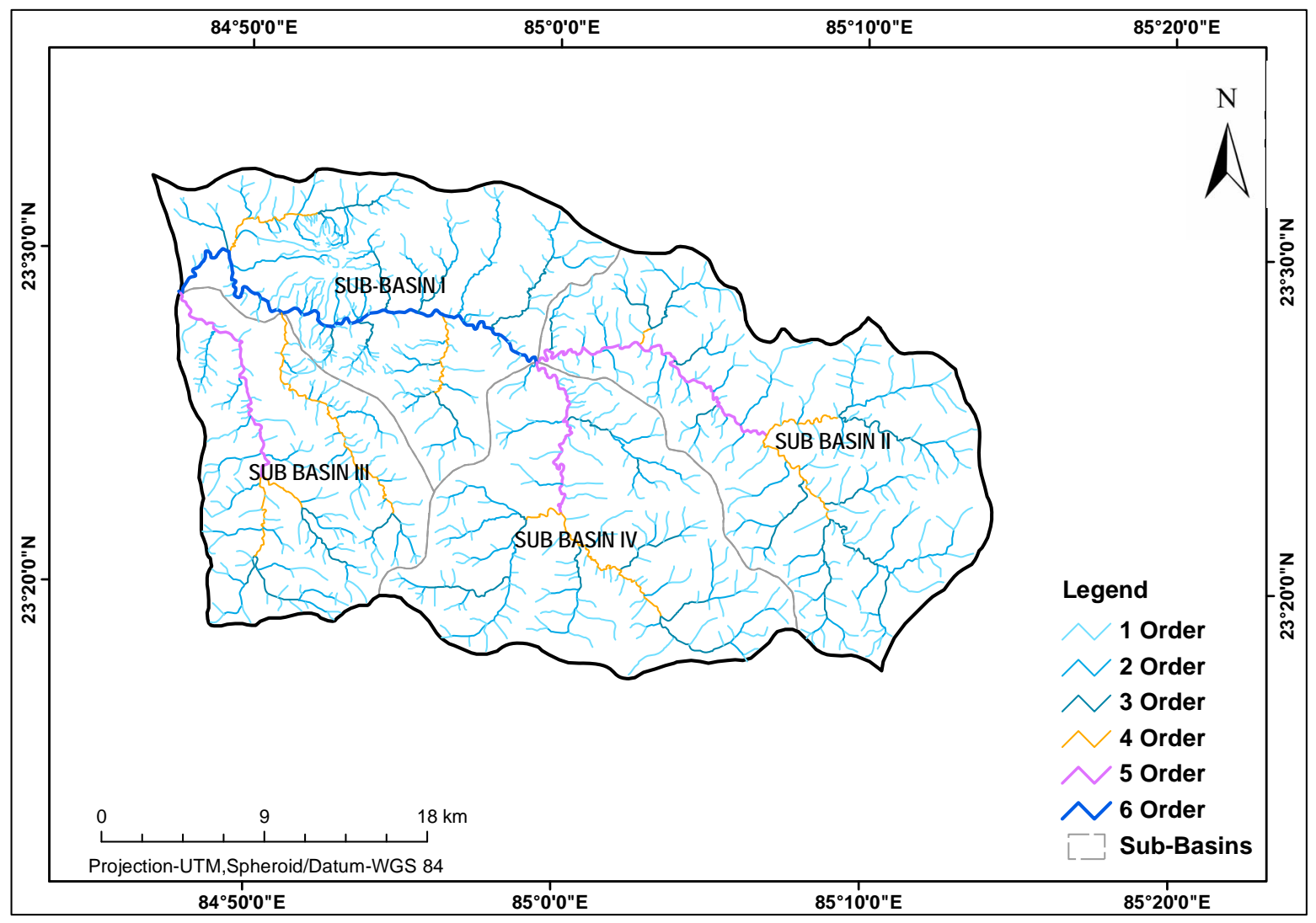

Figure 3. Drainage and sub basin map of study area. 
Table 2. (a) Linear aspects of the Upper South Koel Basin; (b) Linear aspects of the Upper South Koel Basin.

(a)

\begin{tabular}{ccccccccccccccccccc}
\hline $\begin{array}{c}\text { Basin/ } \\
\text { Sub-Basin }\end{array}$ & $\begin{array}{c}\text { Perimeter } \\
\text { (in km) }\end{array}$ & $\begin{array}{c}\text { Area } \\
\text { (in sq km) }\end{array}$ & \multicolumn{4}{c}{ Stream Numbers in Different Orders } & \multicolumn{4}{c}{ Order Wise Total Length of Streams (in km) } \\
\hline & & & N1 & N2 & N3 & N4 & N5 & N6 & Total & N1 & N2 & N3 & N4 & N5 & N6 & Total \\
Sub-Basin I & 74.31 & 234.9 & 199 & 91 & 39 & 23 & & 46 & 398 & 149.64 & 76.13 & 28.62 & 13.1 & 29.52 & 297.01 \\
Sub-Basin II & 80.78 & 290.25 & 177 & 86 & 47 & 19 & 45 & & 374 & 180.74 & 78.34 & 41.15 & 14.19 & 20.22 & 334.64 \\
Sub-Basin III & 56.68 & 175.78 & 152 & 69 & 19 & 37 & 20 & & 297 & 121.09 & 49.95 & 14.51 & 24.57 & 14.35 & 224.52 \\
Sub-Basin IV & 67.09 & 240.24 & 136 & 69 & 32 & 18 & 14 & & 269 & 138.42 & 59.27 & 27.22 & 13.15 & 12.46 & 250.52 \\
$\begin{array}{c}\text { Upper South } \\
\text { Koel }\end{array}$ & 138.42 & 941.17 & 664 & 315 & 137 & 97 & 79 & 46 & 1338 & 589.89 & 263.69 & 111.5 & 65.01 & 47.03 & 29.52 & 1106.64 \\
\hline
\end{tabular}

(b)

\begin{tabular}{cccccccccccccccccccc}
\hline $\begin{array}{c}\text { Basin/ } \\
\text { Sub-Basin }\end{array}$ & \multicolumn{4}{c}{} & \multicolumn{4}{c}{ Mean Stream Length } & \multicolumn{4}{c}{ Stream Length Ratio $\left(\mathbf{R}_{\mathbf{L}}\right)$} & \multicolumn{5}{c}{ Bifurcation Ratio $\left(\mathbf{R}_{\mathbf{b}}\right)$} \\
\hline & $\mathrm{N} 1$ & $\mathrm{~N} 2$ & $\mathrm{~N} 3$ & $\mathrm{~N} 4$ & $\mathrm{~N} 5$ & $\mathrm{~N} 6$ & Total & $2 / 1$ & $3 / 2$ & $4 / 3$ & $5 / 4$ & $6 / 5$ & $1 / 2$ & $2 / 3$ & $3 / 4$ & $4 / 5$ & $5 / 6$ & Mean \\
Sub-Basin I & 0.75 & 0.84 & 0.73 & 0.57 & & 0.64 & 3.53 & 1.12 & 0.86 & 0.78 & & & 2.89 & 2.33 & 1.69 & & 1.38 \\
Sub-Basin II & 1.02 & 0.91 & 0.86 & 0.75 & 0.45 & & 3.99 & 0.89 & 0.94 & 0.87 & 0.6 & & 2.05 & 1.83 & 2.47 & 0.42 & 1.35 \\
Sub-Basin III & 0.8 & 0.72 & 0.76 & 0.66 & 0.72 & & 3.66 & 0.9 & 1.05 & 0.87 & 1.09 & 2.20 & 3.63 & 0.51 & 1.85 & 1.64 \\
Sub-Basin IV & 1.02 & 0.86 & 0.85 & 0.73 & 0.89 & & 4.35 & 0.84 & 0.99 & 0.86 & 1.22 & & 1.97 & 2.15 & 1.78 & 1.28 & 1.44 \\
$\begin{array}{c}\text { Upper South } \\
\text { Koel }\end{array}$ & 0.88 & 0.84 & 0.81 & 0.67 & 0.6 & 0.64 & 4.44 & 0.95 & 0.96 & 0.83 & 0.89 & 1.07 & 2.11 & 2.29 & 1.41 & 1.23 & 1.72 & 1.75 \\
\hline
\end{tabular}

\subsubsection{Stream Length $(L)$}

Stream length is defined as the total length of all streams of each order in the drainage basin. Strahler [7] suggested that the stream length of a particular order is inversely proportional to the stream order i.e. length of stream decreases with increase in stream order. Sub-basin II has highest cumulative length of streams whereas Sub-Basin I has lowest cumulative length of streams.

\subsubsection{Mean Stream Length $\left(L_{\mathrm{sm}}\right)$}

Mean stream length is a characteristic property related to the drainage network components and its associated basin surfaces [7]. Generally, cumulative length of stream of a particular order is measured and the mean length of that order is obtained by dividing the cumulative stream length by number of segments of that order.

The mean stream length in the watershed varies from 0.60 to 0.88 . The mean stream length of any given order is greater than that of the lower order and lesser than that of its next higher order. It is observed that in the watershed, mean stream length decreases with increase in stream order. Such anonymity might be due to variations in slope and topography.

\subsubsection{Stream Length Ratio $\left(R_{L}\right)$}

Stream length ratio is the ratio of the mean length of the one order to the next lower order of the stream segments, which tends to be constant throughout the successive orders of a basin [5]. The stream length ratio between streams of different order in the study area shows variation. The stream length ratio in the watershed varies between $0.82-1.15$. This variation might be attributed to variation in slope and topography, indicating the late youth stage of geomorphic development in the streams of the study area [11].

\subsubsection{Bifurcation Ratio $\left(\mathbf{R}_{\mathbf{b}}\right)$}

According to Schumm [12], the term bifurcation ratio may be defined as the ratio of the number of the stream segments of given order to the number of segments of the next higher orders. The bifurcation ratio in the watershed varies between $1.41-2.29$. The low bifurcation values are indicative of less structural complexity which in turn has not distorted the drainage pattern of the basin [7].

\subsection{Areal Aspects}

The aerial aspects of the drainage basin such as drainage density $\left(D_{d}\right)$, stream frequency $\left(F_{s}\right)$, texture ratio $(T)$, elongation ratio $\left(\mathrm{R}_{\mathrm{e}}\right)$, circularity ratio $\left(\mathrm{R}_{\mathrm{c}}\right)$ and form factor ratio $\left(\mathrm{R}_{\mathrm{f}}\right)$, Length of Overland ratio $\left(\mathrm{L}_{\mathrm{o}}\right)$ were calculated and results have been given in Table 3

\subsubsection{Drainage Density $\left(D_{d}\right)$}

Drainage Density is defined as the total length of streams of all orders per drainage area. It is the measure of closeness of spacing of channels. Slope gradient and relative 
Table 3. Areal aspects of Upper South Koel Basin.

\begin{tabular}{|c|c|c|c|c|c|c|c|}
\hline Basin/Sub-Basin & $\begin{array}{c}\text { Drainage } \\
\text { density } \\
\left(\mathbf{k m}^{-1}\right)\end{array}$ & $\begin{array}{c}\text { Stream } \\
\text { Frequency } \\
\left(\mathbf{k m}^{-2}\right)\end{array}$ & $\begin{array}{c}\text { Texture } \\
\text { Ratio } \\
\left(\mathbf{k m}^{-1}\right)\end{array}$ & $\begin{array}{c}\text { Elongation } \\
\text { Ratio }\end{array}$ & $\begin{array}{c}\text { Circulatory } \\
\text { Ratio }\end{array}$ & $\begin{array}{c}\text { Form } \\
\text { Factor }\end{array}$ & $\begin{array}{l}\text { Length of } \\
\text { Overland } \\
\text { Flow }\end{array}$ \\
\hline Sub-Basin I & 1.26 & 1.69 & 2.13 & 0.74 & 0.53 & 0.43 & 0.40 \\
\hline Sub-Basin II & 1.15 & 1.29 & 1.48 & 0.72 & 0.56 & 0.40 & 0.44 \\
\hline Sub-Basin III & 1.28 & 1.70 & 2.18 & 0.75 & 0.69 & 0.44 & 0.39 \\
\hline Sub-Basin IV & 1.04 & 1.12 & 1.16 & 0.96 & 0.67 & 0.73 & 0.48 \\
\hline Upper South Koel & 1.17 & 1.42 & 1.66 & 0.71 & 0.62 & 0.39 & 0.43 \\
\hline
\end{tabular}

relief are the main morphological factors controlling drainage density. Low density leads to coarse drainage texture while high drainage density leads to fine drainage texture. Drainage Density depends on annual rainfall, infiltration capacity of rocks, vegetation cover, surface roughness and run-off intensity. Low drainage density is favoured in regions of highly resistant and permeable subsoil and low relief. High Drainage density on the other hand is favoured in regions of impermeable rocks; high relief. The Drainage Density for the whole basin is $1.17 \mathrm{~km} / \mathrm{km}^{2}$ indicating that the basin is not much affected by structural disturbances. The drainage density of the four sub-basins is given in Table 3.

\subsubsection{Stream Frequency $\left(F_{u}\right)$}

The total number of stream segments of all orders per unit area is known as stream frequency [13]. Stream frequency exhibits a positive correlation with drainage density suggesting an increase in stream population with increasing drainage density. It mainly depends on the lithology of the basin and reflects the texture of the drainage network.

The stream frequency for the whole watershed is 1.42 $\mathrm{km} / \mathrm{km}^{2}$ indicating low relief and permeable sub surface material. The $\mathrm{F}_{\mathrm{u}}$ for the sub-basins is given in Table 3.

\subsubsection{Texture Ratio (T)}

Drainage texture is one of the important concepts of geomorphology which means the relative spacing of drainage lines. The drainage texture $(\mathrm{T})$ depends upon a number of natural factors such as climate, rainfall, vegetation, rock and soil type, infiltration capacity, relief and stage of development [14]. Drainage lines are numerous over impermeable areas than permeable areas. According to Smith [14], $\mathrm{T}$ is the product of drainage density and stream frequency and has classified drainage texture into five different textures. The drainage texture less than 2 indicates very coarse, between 2 and 4 is related to coarse, between 4 and 6 is moderate, between 6 and 8 is fine and greater than 8 is very fine drainage texture.

The drainage texture for the whole watershed is 1.66 indicating very coarse texture. $T$ values of sub-basins are given in Table 3.

\subsubsection{Form Factor $\left(R_{f}\right)$}

Form Factor is defined as the ratio of the basin area to the square of the basin length. Horton [5] proposed this parameter to predict the flow intensity of a basin of a defined area. The value of form factor would always be greater than 0.78 for a perfectly circular basin. Smaller the value of form factor, more elongated will be the basin. Basins with high-form factors experience larger peak flows of shorter duration, whereas elongated watersheds having low-form factors experience lower peak flows of longer duration.

The $\mathrm{R}_{\mathrm{f}}$ of the whole basin is 0.39 indicating that the watershed is an elongated one and experience low peak flows for long duration. The $\mathrm{R}_{\mathrm{f}}$ of the sub-basins is given in Table 3.

\subsubsection{Elongation Ratio $\left(R_{\mathbf{e}}\right)$}

Schumn [12] defined elongation ratio as the ratio between the diameter of the circle of the same area as the drainage basin and the maximum length of the basin. The discharge characteristics of any watershed are controlled by the elongation ratio. Elongation ratio also determines the shape of the watershed and can be classified based on these values as circular $(0.9-1)$, oval $(0.8-0.9)$, less elongated $(0.7-0.8)$, elongated $(0.5-0.7)$, more elongated $(<0.5)$. Regions with low elongation ratio values are susceptible to more erosion whereas regions with high values correspond to high infiltration capacity and low runoff. The elongation ratio of the watershed is 0.71 indicating that the basin is less elongated and less prone to erosion. The $\mathrm{R}_{\mathrm{e}}$ values of the sub-basins are given in Table 3.

\subsubsection{Circulatory Ratio $\left(\mathbf{R}_{\mathrm{c}}\right)$}

Circularity ratio is defined as the ratio of watershed area to the area of a circle having the same perimeter as the watershed. Circulatory ratio is influenced by the length and frequency of streams, geological structures, land use/land cover, climate, relief and slope of the basin. 
$R_{c}$ values approaching 1 indicates that the basin shapes are like circular and as a result, it gets scope for uniform infiltration and takes long time to reach excess water at basin outlet. The $R_{c}$ of the whole basin is 0.62 , while those of the 5 sub-basins are shown in Table 3 . It is a significant ratio, which indicates the dentritic stage of a basin.

\subsubsection{Length of Overland Flow $\left(L_{0}\right)$}

It is the length of water over the ground before it gets concentrated into definite stream channels. Length of overland flow is one of the most important independent variables affecting hydrologic and physiographic development of drainage basin. The average length of overland flow is approximately half the average distance between stream channels and is therefore approximately equals to half of reciprocal of drainage density (Horton, 1945). Higher value of $L_{o}$ is indicative of low relief and where as low value of $\mathrm{L}_{\mathrm{o}}$ is an indicative of high relief.

The length of overland flow value for the watershed is 0.43 .

\subsection{Relief Aspects}

\subsubsection{Relief}

Strahler [6] described the basin relief as the maximum vertical difference between the highest and lowest elevation within the basin. Basin Relief plays a significant role in landforms development, drainage development, surface and subsurface water flow, permeability and erosional properties of the terrain. The relative basin relief is $80 \mathrm{~m}$. The sub-basin relative relief values are given in Table 4.

\subsubsection{Relief Ratio}

The maximum relief to horizontal distance along the longest dimension of the basin parallel to the principal drainage line is termed as relief ratio [12]. It is the ratio of basin relief to basin length. While high values are characteristic of hill regions low values are characteristic of pediplains and valley. The relief ratio of the watershed is 0.002 while those of the sub-basins are given in Table 4. The lower values may indicate the presence of basement rocks that are exposed in the form of small ridges and mounds with lower degree of slope [15]. Low relief ratios also indicate that the discharge capabilities of the watershed are low and chances of groundwater potential are good.

\subsubsection{Slope}

Slope is an important parameter in geomorphic studies. An understanding of slope distribution is essential as it plays a significant role in determining infiltration vs. runoff relation. Infiltration is inversely related to slope i.e. gentler is the slope, higher is infiltration and less is runoff and vice-versa.

The average elevation of the area varies between 640 $\mathrm{m}$ to $925 \mathrm{~m}$. Slope analysis showed that slope in the study area varies from 0 to $21^{\circ}$ with mean slope of $0.66^{\circ}$ and slope standard deviation of $1.37^{\circ}$. High slope is witnessed in the north western part of the watershed. Figure 4 shows the slope map of the watershed.

\section{Drainage Morphometry and Its Influence on Geomorphology}

The underlying geology, exogenic and endogenic activities, drainage morphometry and considerable changes in climate during the Quaternary, influ ences the genesis and morphology of landforms [16]. Structural hill, pediment, and valley fills and pediplains formed by the influence of permeable geology, are moderate to nearly level plains, with medium to low drainage density $(<2.0)$, low cumulative length of 4th and 5th order streams. On the other hand landforms like the Hill top plains/dissected plateau landforms are associated with high drainage density, bifurcation ratio and high cumulative length of first, second and third order streams.

Denudational processes are actively involved in landscape reduction processes. In the present study, the different geomorphic units (Figure 5) i.e. Structural Hill,

Table 4. Relief aspects of Upper South Koel Basin.

\begin{tabular}{|c|c|c|c|c|c|}
\hline \multirow[t]{2}{*}{ Basin/Sub-Basin } & \multicolumn{2}{|c|}{ Elevation in $\mathrm{m}$} & \multirow{2}{*}{$\begin{array}{c}\text { Relative Relief } \\
\text { (H-h) in m }\end{array}$} & \multirow{2}{*}{$\begin{array}{c}\text { Basin Length } \\
\text { in } \mathrm{km}\end{array}$} & \multirow{2}{*}{$\frac{\text { Relief Ratio }}{(\mathrm{H}-\mathrm{h}) / \mathrm{L}}$} \\
\hline & Max H' & Min h' & & & \\
\hline Sub-Basin I & 700 & 640 & 60 & 23.45 & 0.002 \\
\hline Sub-Basin II & 740 & 660 & 80 & 26.85 & 0.003 \\
\hline Sub-Basin III & 740 & 640 & 100 & 20.08 & 0.005 \\
\hline Sub-Basin IV & 720 & 660 & 60 & 18.15 & 0.003 \\
\hline Upper South Koel & 740 & 660 & 80 & 49.07 & 0.002 \\
\hline
\end{tabular}




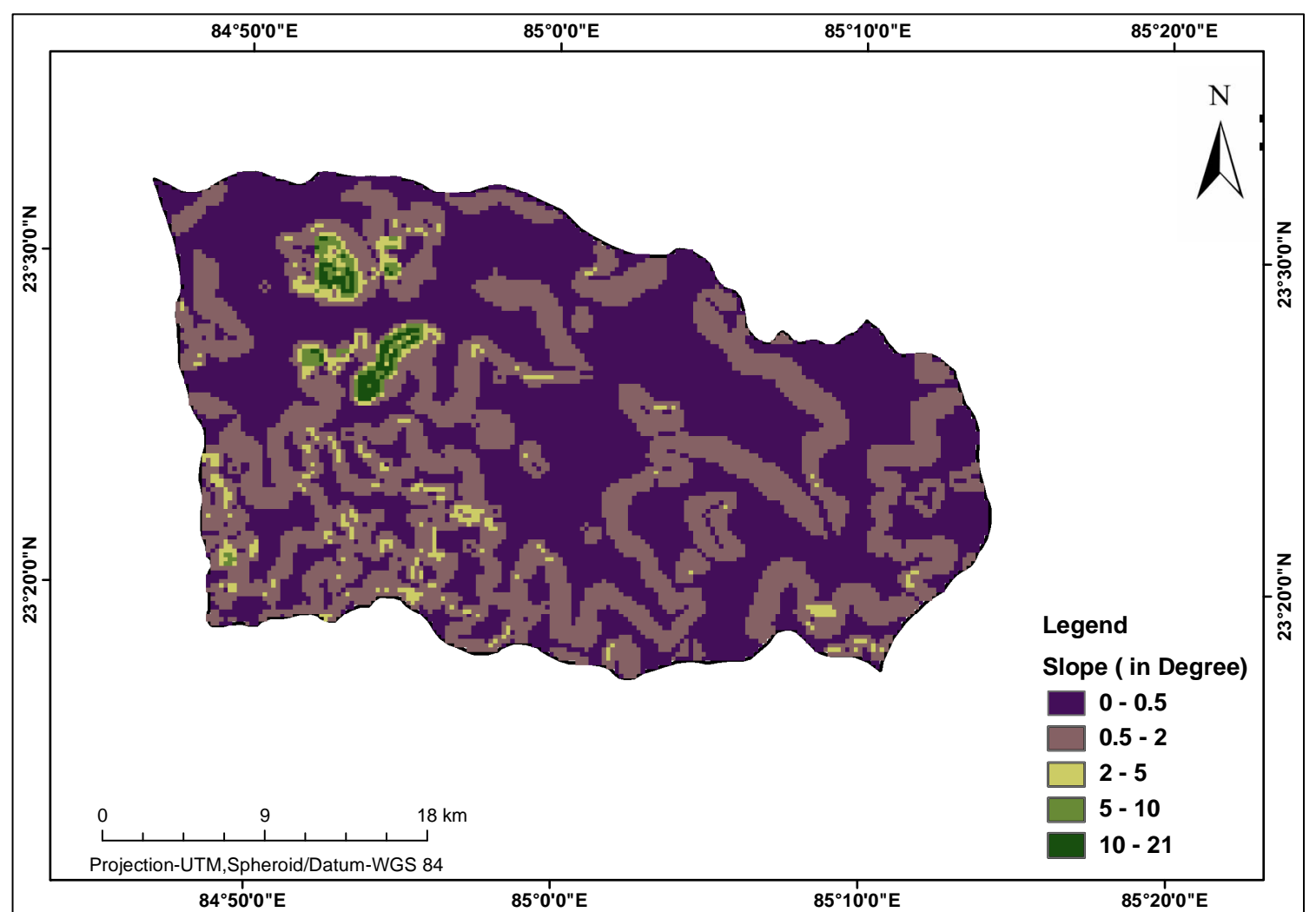

Figure 4. Slope map of study area.

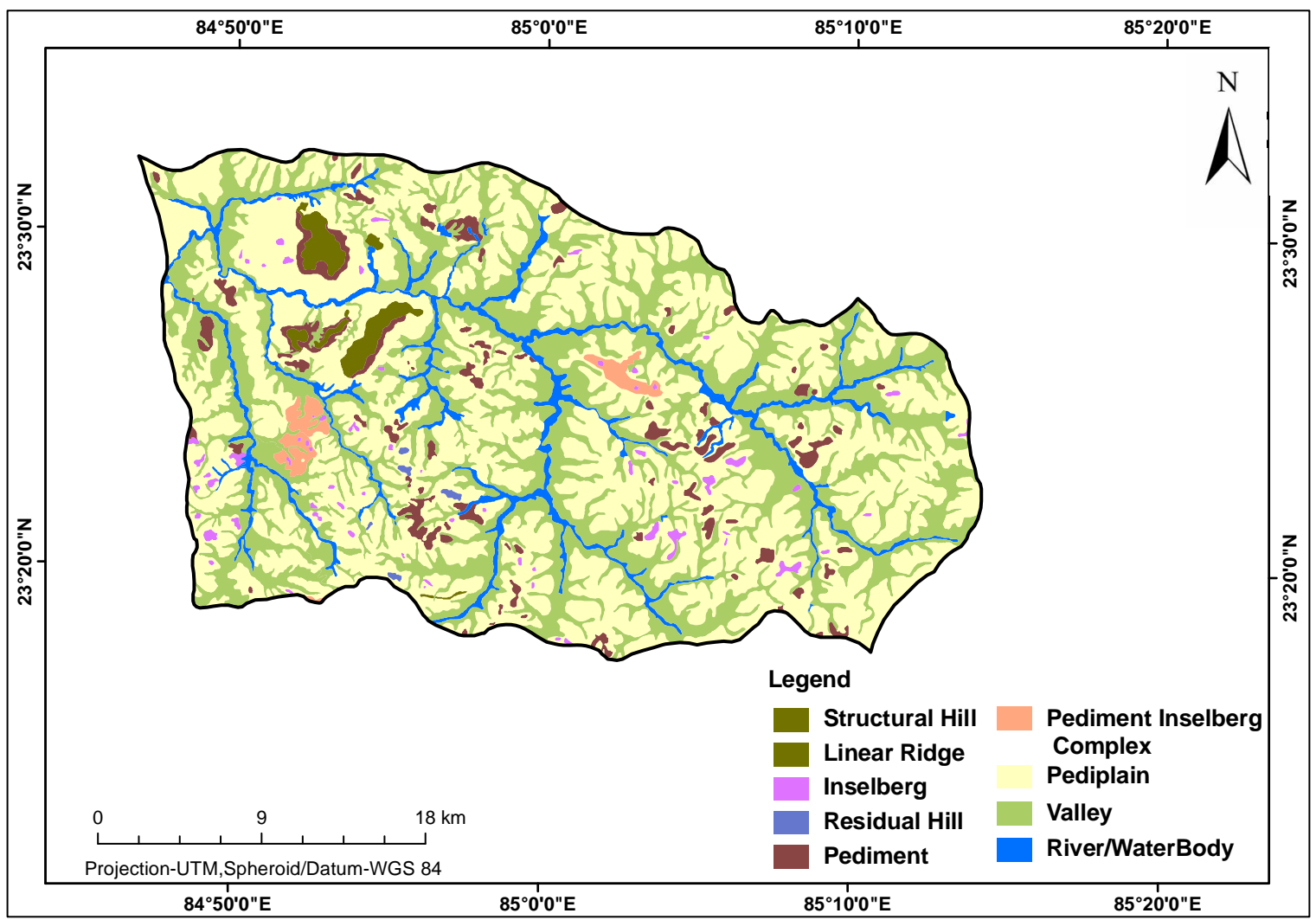

Figure 5. Geomorphology map of study area. 
Pediments, Pediplain, Valley, Ridges have been delineated based on image characteristics. Valleys are the unconsolidated sediments deposited by streams/rivers, normally in narrow fluvial valley and constitute boulders, cobbles, pebbles; gravels, sand and silt, cover nearly $34.5 \%$ of the study area. Pediplains are gently sloping, smooth surfaces of erosional bed rocks resulting from coalescence of two or more pediments. Pediplains occupy $52.25 \%$ of the total study area. Structural hills comprising meta-igneous rocks show linear to arcuate pattern covering $1.39 \%$ of the area. Pediments occur at the foot hills and occupy $11.86 \%$ of the study area.

\section{Conclusion}

The study reveals that GIS and remote sensing can be very useful in evaluation of various morphometric parameters and its influence on landforms. Interpretation of satellite images can help delineate lithological and geomorphic units. GIS facilitates analysis of various morphometric parameters and acts as an effective tool in establishing relationship between drainage morphometry and properties of landforms. The study also reveals that DEM can useful in studying the topography within GIS environment. Geomorphological study of an area is the systematic study of present day landforms, related to their origin, nature, development, geologic changes recorded by the surface features and their relationship to other underlying structures. Therefore, it has become an integral part of groundwater study of an area. Some morphometric elements (measurement of landforms) provide valuable information for groundwater condition. The morphometric parameters evaluated using GIS helped to understand various terrain parameters such as nature of the bedrock, infiltration capacity, runoff, etc. Similar studies in conjunction with high resolution satellite data help in better understanding the landforms and their processes and drainage pattern demarcations for basin area planning and management [17].

\section{REFERENCES}

[1] J. C. Doornkamp and A. M. K. Cuchlaine, "Numerical Analysis in Geomorphology-An Introduction," Edward Arnold, London, 1971.

[2] A. N. Strahler, "Quantitative Analysis of Watershed Geomorphology," Transactions-American Geophysical Union, Vol. 38, No. 6, 1957, pp. 913-920.

[3] H. Verstappen, "The Applied Geomorphology," International Institute for Aerial Survey and Earth Science (I.T.C), Enschede, 1983.

[4] R. Kumar, S. Kumar, A. K. Lohani, R. K. Nema and R. D. Singh, "Evaluation of Geomorphological Characteristics of a Catchment Using GIS," GIS India, Vol. 9, No. 3,
2000, pp. 13-17.

[5] R. E. Horton, "Erosional Development of Streams and Their Drainage Basins: Hydrophysical Approach to Quantitative Morphology," Bulletin Geological Society of America, Vol. 56, 1945, pp. 275-370. doi:10.1130/0016-7606(1945)56[275:EDOSAT]2.0.CO;2

[6] A. N. Strahler, "Dynamic Basis of Geomorphology," Bulletin Geological Society of America, Vol. 63, No. 9, 1952, pp. 923-938. doi:10.1130/0016-7606(1952)63[923:DBOG]2.0.CO;2

[7] A. N. Strahler, "Quantitative Geomorphology of Basins and Channel Networks," In: V. T. Chow, Ed., Handbook of Applied Hydrology, Mcgraw Hill Book Company, New York, 1964.

[8] M. E. Morisawa, "Relation of Morphometric Properties to Runoff in the LiHle Mill Creek, Ohio, Drainge Basin," Tech Report 17, Columbia University, Department of Geology, New York, 1959.

[9] L. B. Leopold and J. P. Miller, "Ephemeral Streams: Hydraulic Factors and Their Relation to the Drainage Network," US Geological Survey, 1956.

[10] J. Krishnamurthy, G. Srinivas, V. Jayaram and M. G. Chandrasekhar, "Influence of Rock Types and Structures in the Development of Drainage Networks in Typical Hard Rock Terrain," ITC Journal, No. 3/4, 1996, pp. 252259.

[11] S. Singh and M. C. Singh, "Morphometric Analysis of Kanhar River Basin," National Geographical Journal of India, Vol. 43, No. 1, 1997, pp. 31-43.

[12] S. A. Schumm, "Evolution of Drainage Systems and Slopes in Bad Lands at Perth Amboy, New Jersey," Bulletin Geological Society of America, Vol. 67, No. 5, 1956, pp. 597-646.

[13] R. E. Horton, "Drainage Basin Characteristics," Transactions-American Geophysical Union, Vol. 13, 1932, pp. 350-361.

[14] K. G. Smith, "Standards for Grading Texture of Erosional Topography," American Journal of Science, Vol. 248, 1950, pp. 655-668. doi:10.2475/ajs.248.9.655

[15] R. Datt and N. L. Ramanathan, "Environmental Monitoring," Proceedings of Seminar on the Status of Environmental Studies in India, Thiruvananthapuram, 26-28 March 1981, pp. 284-287.

[16] V. Subramnyan, "Geomorphology of the Deccan Volcanic Province, India," In: K. V. Subbarao and R. N. Sukheswala, Eds., Deccan Volcanism and Related Basalt Provinces in Other Parts of the World, Memoir No. 3, GSI, Bangalore, 1981, pp. 101-116.

[17] M. Bagyaraj and B. Gurugnanam, "Significance of Morphometry Studies, Soil Characteristics, Erosion Phenomena and Landform Processes Using Remote Sensing and GIS for Kodaikanal Hills, a Global Biodiversity Hotpot in Western Ghats, Dindigul District, Tamil Nadu, South India," Research Journal of Environmental and Earth Sciences, Vol. 3, No. 3, 2011, pp. 221-233. 